\title{
Assessing and factoring in investment barriers for making long-term projections of the energy sector
}

\author{
Y. D. Kononov*, D. Y. Kononov
}

Melentiev Energy Systems Institute of Siberian Branch of Russian Academy of Sciences, Irkutsk, Russia

\begin{abstract}
This study deals with the issue of a quantitative assessment of barriers to the energy sector development as an important stand-alone problem of making projections. To solve it, it is proposed to use iterative calcula-tions as performed by the system of optimization and stochastic models and factor in investment risks.
\end{abstract}

Index Terms - projections, energy, economy, uncertainty, barriers, risks.

\section{INTRODUCTION}

When making projections for the energy sector one has to consider multiple cases of its development as harmonized with the national economic growth scenarios, volumes, and the structure of exports and imports, the anticipated change in pricing, tax policy, and the governance framework. The growth rates of the energy sector industries as well as the speed of their structural changes that can be attained within each time period are limited, so arbitrary high demand for energy carriers proves impossible to meet. A possible bottleneck can manifest itself as a lack of time or that of materials, funding, and labor necessary for new capacity additions not in the energy sector itself but in its supporting industries.

Barriers are defined as existing bottlenecks that can potentially hinder the development of the energy industry under the conditions anticipated for a given time period. They are identified by juxtaposing the energy sector development requirements and the capacity to meet them. Quantitative estimates of barriers can serve as constraints in economic and mathematical models that are employed for making projections. The list of barriers should be tailored

\footnotetext{
${ }^{*}$ Corresponding author.

E-mail: kononov@isem.irk.ru
}

http://dx.doi.org/10.38028/esr.2020.01.0002

Received April 06, 2020. Revised May 30, 2020.

Accepted June 20, 2020. Available online July 31, 2020.

This is an open access article under a Creative Commons Attribution-NonCommercial 4.0 International License.

(C) 2020 ESI SB RAS and authors. All rights reserved. to a specific problem and a given hierarchical level. In doing so, it is reasonable to distinguish between constraints and barriers that are exogenous and endogenous to a given hierarchical level (system) (see Table 1).

The most significant internal constraints to be addressed while making projections of the energy sector are time barriers that are due to the inertia of the energy systems development. The latter manifests itself, in particular, as an inability to sharply increase production volumes within a short time period, to change the composition of facilities in individual industries of the energy sector as well as the makeup of the national energy balance.

Investment and resource barriers are also a serious obstacle to accelerating development, modernizing production, and adding new capacity. Investment barriers are related to price barriers and limited demand for energy carriers as financial resources required for making investments to a significant degree are a function of profits. In the case of individual energy companies and supplying companies, the market price may prove to be a barrier if it turns out lower than levelized costs (that is minimum acceptable supply prices that mark the threshold value below which the production and delivery of fuel and energy are considered to be uneconomical). The price barrier for a given energy carrier for the consumer arises in the case when its expected price proves unacceptable on economic grounds or for some other reasons and there is an alternative solution available.

High uncertainty of future demand and prices for energy carriers as well as the values of other input parameters result in challenges in estimating the return of prospective projects, especially in the cases of the valuation of development options for the energy systems of individual industries and regions. The larger the uncertainty, the higher investment risks, and the lower the probability of providing the required funding and other resources for planned new capacity additions. The combination of factors that are unfavorable for investors such as uncertainty, risks, insufficiently high performance, and time constraints may become a major barrier for new capacity additions in the energy sector industries. A valid quantitative assessment of this compound barrier is one of the important problems to be solved as part of making projections. 
Table 1. Constraints on the development of energy systems at different hierarchical levels.

\begin{tabular}{|c|c|c|}
\hline \multirow{2}{*}{ Hierarchical level } & \multicolumn{2}{|c|}{ Constraints } \\
\hline & exogenous & endogenous \\
\hline $\begin{array}{l}\text { The national energy } \\
\text { sector }\end{array}$ & $\begin{array}{l}\text { Demand for energy carriers, limits on potential } \\
\text { exports and imports of the energy sector products, } \\
\text { prices on international and domestic energy markets, } \\
\text { indicators of national security and energy security, } \\
\text { limits on } \mathrm{CO}_{2} \text { emissions }\end{array}$ & $\begin{array}{l}\text { Production volumes and development times of major centers } \\
\text { of fuel production, the potential for new capacity additions in } \\
\text { the electric power industry and the fuel industry }\end{array}$ \\
\hline Regional energy sectors & $\begin{array}{l}\text { Demand for fuel and energy, prices. Cross-regional } \\
\text { energy links Environmental and social requirements }\end{array}$ & $\begin{array}{l}\text { Proven reserves of fuel and energy resources, required time } \\
\text { and volumes of new capacity additions in the electric power } \\
\text { industry and the fuel industry within the region }\end{array}$ \\
\hline $\begin{array}{l}\text { Systems of individual } \\
\text { industries }\end{array}$ & $\begin{array}{l}\text { Volumes and patterns of demand for products of a } \\
\text { given industry, potential for its exports, market } \\
\text { prices, executive directives, terms of reference, and } \\
\text { regulations. }\end{array}$ & $\begin{array}{l}\text { The scale and required time for the potential development of } \\
\text { mineral deposits and new capacity additions. Available } \\
\text { capital expenditures. Availability and capacity of major } \\
\text { transport links. Constraints on the development of individual } \\
\text { companies (as applied to new capacity additions by regions). }\end{array}$ \\
\hline Companies, businesses & $\begin{array}{l}\text { Demand for company's products, market prices, } \\
\text { export and import opportunities, competition, } \\
\text { infrastructural constraints, executive directives. }\end{array}$ & $\begin{array}{l}\text { Available production capacity (assets, technologies, labor, } \\
\text { reserves). Financial resources. Performance of projects and } \\
\text { their investment risks. The time required for construction and } \\
\text { modernization }\end{array}$ \\
\hline
\end{tabular}

Note. The table presents the main constraints that are factored in the development, assessment, and choice of the options for developing the energy sector.

\section{INCREMENTAL NARROWING DOWN OF THE UNCERTAINTY RANGE OF SPECIFIED INVESTMENT BARRIERS}

Taking into account the interdependence of barriers and improving the validity of their numerical evaluation are facilitated by an incremental approach that relies on the mutable mix of economic and mathematical models at different stages of making projections and at different hierarchical levels (Fig. 1).

The optimization models used when making projections for the energy sector can allow for the investment barriers in the assumed constraints on available capital expenditures or new capacity additions. They can be roughly defined and specified when using an iterative calculation scheme at the levels of the national energy sector, the electric power industry and fuel industry, regional power supply systems, and energy companies.

In the course of iterative calculations, the solutions obtained in optimization models of each hierarchical level get adjusted, and the specified constraints are refined. This changes the degree of aggregation of a geographical area, input data, and barriers, which increases when moving to a lower hierarchical level and decreases (gets aggregated) when moving the bottom-up way.

A non-exhaustive list of indicators linking the models of the energy sector, the electric power industry, and regional power supply systems is shown in Table 2.

At the lower level, the hierarchy of models can simulate the behavior of potential investors and determine financial performance and investment risks of new capacity additions to ensure rational energy supply to consumers in the area under consideration. For this purpose, it is reasonable to use a combination of optimization with the well-established Monte Carlo method [2]. A model (its software implementation) of this kind named MISS-EL was developed at the Melentiev Energy Systems Institute SB RAS [3]. It has all inputs specified not as point estimates, but as ranges of values with the indication of the nature of

Table 2. Main information links between models at different hierarchical levels when identifying and refining the information on investment barriers.

\begin{tabular}{|c|c|c|c|}
\hline \multirow{2}{*}{$\begin{array}{l}\text { Hierarchical (model) } \\
\text { levels }\end{array}$} & \multirow{2}{*}{$\begin{array}{l}\text { Degree of } \\
\text { aggregation of the } \\
\text { geographical area }\end{array}$} & \multicolumn{2}{|c|}{ Information to be obtained and refined } \\
\hline & & from the upper level & to the upper level \\
\hline $\begin{array}{l}\text { The national energy } \\
\text { sector }\end{array}$ & Marcoregions & $\begin{array}{l}\text { Demand for energy and exports of fuel and } \\
\text { electricity. Fuel prices. The share of the } \\
\text { energy sector in the total capital } \\
\text { expenditures. Environmental requirements } \\
\text { for the energy sector. }\end{array}$ & $\begin{array}{l}\text { Adjustments with respect to fuel extraction, } \\
\text { electricity production, and energy prices. Capital } \\
\text { expenditures required by the energy sector. CO2 } \\
\text { emissions. Estimates of sustainability and } \\
\text { security of options of energy sector development. }\end{array}$ \\
\hline $\begin{array}{l}\text { Electric power } \\
\text { industry }\end{array}$ & $\begin{array}{l}\text { Federal districts, } \\
\text { IEPS } \\
\text { (interconnected } \\
\text { power systems) }\end{array}$ & $\begin{array}{l}\text { Constraints on fuel resources for power } \\
\text { plants. Gas and coal prices for power } \\
\text { plants. }\end{array}$ & $\begin{array}{l}\text { Constraints on new capacity additions of nuclear } \\
\text { power plants (NPPs) and renewable energy } \\
\text { sources (RES). Cost of electricity generation and } \\
\text { transport. Demand for fuel by power plants } \\
\text { Required capital expenditures and strategic } \\
\text { threats to electric power industry development. }\end{array}$ \\
\hline $\begin{array}{l}\text { Energy companies } \\
\text { Regional energy } \\
\text { supply systems. }\end{array}$ & $\begin{array}{l}\text { Regions, wholesale } \\
\text { generating } \\
\text { companies, and } \\
\text { territorial generating } \\
\text { companies }\end{array}$ & $\begin{array}{l}\text { Demand for electricity and heat. } \\
\text { Constraints on gas supplies. Fuel prices. } \\
\text { Constraints on cross-regional power } \\
\text { transfers. }\end{array}$ & $\begin{array}{l}\text { Investment risks of RES and other new power } \\
\text { plants. Estimates of the energy security of } \\
\text { regions. Share of distributed generation. }\end{array}$ \\
\hline
\end{tabular}


Time frame

un to 10 to 15 vears

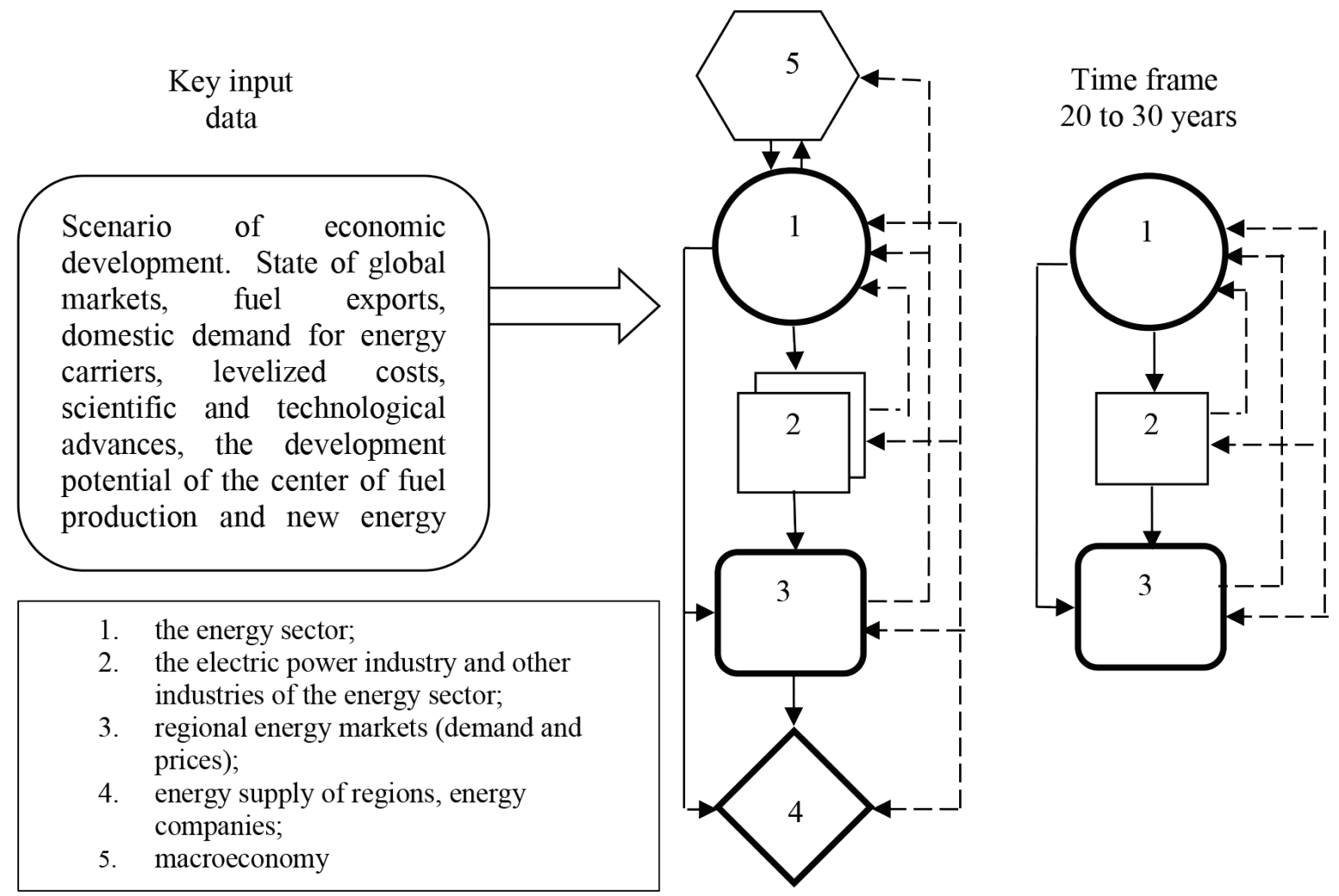

Figure 1. Relationships between models used in different stages of making projections of the energy sector [1].

probability distribution within such intervals. The adopted criterion of optimality is the minimum of discounted costs for electricity generation and transport.

Investment risks of individual groups of new power plants are determined by the frequency of their occurrence (with a certain capacity) in the solutions that are considered to be optimal under various conditions. The ratio of this indicator to the total number of solutions (hundreds of calculations) allows judging the probability of the implementation of the project of individual plants. The lower the probability the higher the investment risks.

The bottom-up calculations performed by the system of models allow consistent identification (adjustment) of investment risks of large-scale projects (at the level of energy supply of regions and energy companies), threats of the power shortage (at the level of an individual industry), constraints on new capacity additions in the energy sector and capital expenditures required for its development.

At the next iteration of calculations of the optimization model of the energy sector, its regional structure, and constraints on the new capacity additions that have unacceptably high investment risks can be changed. Directions and transfer capabilities of cross-regional energy ties may also be adjusted to mitigate the threat of a possible power shortage.

\section{IMPACT OF THE DISCOUNT RATE ON INVESTMENT RISKS AND RATIONAL MIX OF POWER PLANTS}

In the optimization models of the energy sector and the electric power industry, the criterion for rational choice is usually the minimum of discounted cash costs required to meet a given demand for energy carriers under given constraints.

In the planned economy of the USSR, normative coefficients of efficiency of capital expenditures were used to make annual operating costs and lump sum investment costs commensurate. The values of these coefficients were assigned separately for different industries, varying from 0.1 to 0.33 [4]. The highest values were applied to the chemical industry and consumer goods manufacturing, while the lowest values were used for energy and transport.

In a market economy, the economic performance of both individual investment projects and development options of entire industries is determined based on the net present value. Discount rates used to this end are a characteristic of the rate of return required by investors with respect to committed capital in terms of the comparable risk level of the investment object. They include two main components: that is, risk-free (guaranteed return on investment) and risky (risk premium) components. The numeric value of the former is mainly based on the base rate of the Central Bank 


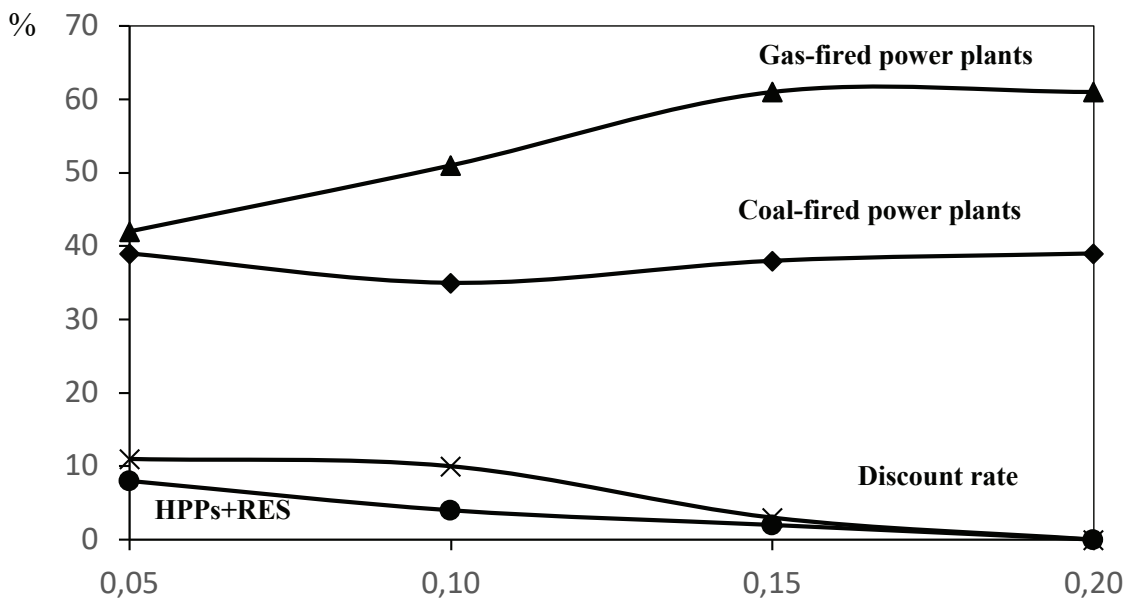

Note. Results of modeled calculations using the optimization (stochastic) model of power supply options for the European part of Russia under expected conditions for years 2025 to 2030 .

\begin{tabular}{|l|l|}
\hline 0,05 & 0.05 \\
\hline 0,10 & 0.10 \\
\hline 0,15 & 0.15 \\
\hline 0,20 & 0.20 \\
\hline
\end{tabular}

Fig. 2. The effect of the discount rate on the mix of new power plants additions.

of Russia and currently amounts to $6-8 \%$ (net of inflation). In EU countries, the risk-free discount rate ranges from $1 \%$ to $7 \%$ [5].

The range of uncertainty of the risk component of the discount rate is significantly larger. The "Guidelines on the methods of the valuation of investment projects" [6] notice that the issue of specific numeric values of risk allowances for different industries and different types of projects has been poorly studied. According to these guidelines, the recommended values of these allowances are: $3-5 \%$ for investment in the development of manufacturing based on the mature equipment, $8-10 \%$ for an increase in the volume of sales of existing products, $13-15 \%$ - for manufacturing and market promotion of new products, $18-20 \%$ - for investment in R\&D and innovations. In investment projects that adopt a new technology under conditions of unstable demand and prices, it can reach $18 \%$ to $23 \%$ [7], and in some cases, it can be as high as $47 \%$ [8].

When deciding on rational options for the development of entire industries, rather than individual enterprises and companies, instead of commercial discount rates one should use social (fiscal) ones that factor in not only economic but also social, environmental, and other possible consequences of an investment.

There are no generally accepted methods for estimating the values of discount coefficients when optimizing the development of the energy sector and the systems of its individual industries. At the same time, as shown by model calculations as performed by the MISS-EL model, their value strongly influences the optimization results. As the discount rate increases, the relative efficiency and competitiveness of the most capital-intensive power plants (hydroelectric, nuclear, solar, and wind power plants) decreases. Accordingly, their share in the mix of the new capacity additions decreases (Fig. 2). The average generation cost in the given geographic area also rises: by about $30 \%$ when the discount rate changes from 0.1 to 0.2 . Investment risks of projects of some power plants (coal-fired CHP plants and HPPs) do not respond so straightforwardly to changes in discount rates (Table 3).

Table 3. Dependence of investment risks on discount rate, $\%$.

\begin{tabular}{lccc}
\hline \multirow{2}{*}{ Power plant type } & & Discount rate & 0.15 \\
\cline { 2 - 4 } & 0.05 & 0.10 & 0.20 \\
\hline Gas-fired: condensing power plants & 93 & 3.7 & 0 \\
CHPPs & 12 & 0.8 & 0.1 \\
\hline Coal-fired: condensing power plants & 2 & 0.1 & 0 \\
CHPPs & 29 & 43 & 25 \\
\hline NPPs & 11 & 27 & 90 \\
\hline HPPs & 0.6 & 16 & 99 \\
\hline RES & 5 & 68 & 2 \\
\hline $\begin{array}{l}\text { The weighted average risk of new power } \\
\text { plants in the aggregated region }\end{array}$ & 22 & 8 & 4 \\
\hline \hline
\end{tabular}


Such a response is due to the fact that in the calculations there were no changes in constraints on gas supplies as well as upper limits of permissible cross-regional power transfers and new capacity additions of CHP plants and NPPs.

It is worth noting that the presented results of calculations are obtained given the normal distribution of input data within specified ranges of their probable values. In the case of interval (equiprobable) uncertainty, the value of investment risks is significantly higher (approximately twice that much).

Note. Results of modeled calculations using the MISSEL model for one of the power supply scenarios of the European part of Russia (inclusive of the Urals).

Calculations and analysis of the principles and practices adopted in Russia and abroad enable us to propose the following approach to the assignment of the discount rate in optimization models used at different hierarchical levels and different temporal stages of making projections of long-term development of the energy sector:

- In the optimization models of the country's energy sector, the discount rate should reflect the social and fiscal significance of the compared options, and the value of the risk component should be less than that in the case of the optimization of the development of the electric power industry and especially the gas industry, taking into account the specificity of external and internal conditions and the significance of strategic threats.

- When optimizing the development of regional power supply systems due to particularly high uncertainty of future conditions, the issue of discounting proves particularly challenging. Therefore, the assessment of investment risks should be seen as a problem of its own and should be solved using the Monte Carlo method.

- The risk-free component of the discount rate, currently assumed to be $6-8 \%$, should decrease with an increase in the projection time frame (to about 5-6\%), and the risk component should increase (with an increase in uncertainty).

\section{CONCLUSION}

The need for quantitative assessment of barriers and investment risks arises in various stages of making projections of the energy sector development. Such an assessment is needed to improve the validity of longterm projections, narrow down the range of uncertainty in development conditions, and identify possible challenges and strategic threats to energy security [10], [11].

Lack of financial and other resources may become one of the main threats of new capacity additions in the electric power industry and other systems of individual industries of the energy sector lagging behind the growing demand for them. Identification of the plausibility and significance of this strategic threat should be based on quantitative assessment of investment risks of both individual large-scale projects and options of the energy industry development of the country.

The proposed approach to a comprehensive assessment of investment barriers and risks assumes an incremental narrowing down of the uncertainty range in the energy sector development and the use of a system of optimization and stochastic models. Iterative calculations by these models at different hierarchical levels (performed in the top-down and bottom-up fashions) allow narrowing down the uncertainty range of possible dynamics of prices and demand for energy carriers. This, in turn, yields important information for the assessment of the performance and risk of large-scale projects and clarification of the required and possible capital expenditures.

Estimates of the riskiness of development options for energy systems should be reflected in energy security indicators. Some suggestions as to their mix are presented, for example, in [9].

Obviously, the rational ways of analyzing the projection range and assessing quantitatively investment and other barriers and risks depend on the time frame in question, the magnitude and nature of uncertainty of the input data, and the importance of the projection results for strategic decision-making.

\section{ACKNOWLEDGMENTS}

The research was carried out under State Assignment III.17.5.2 (reg. No. AAAA-A17-117030310452-7) of the basic research of the SB RAS and was supported by t RFBR grant (Project No. 20-010-00204, No. 18-010-00176).

\section{REFERENCES}

[1] Yu. D. Kononov. Approaches to improve the validity of long-term projections of the energy sector development. Novosibirsk: Nauka, 2015. 147 p. (In Russian)

[2] S. M. Ermakov. Monte Carlo methods and related issues. Moscow: Nauka, 1975. 472 p. (In Russian)

[3] Yu.D. Kononov, V.N. Tyrtyshny. Assessment of the impact of the nature of uncertainty in future conditions on the competitiveness of fuel supply options, Energy policy. 2011. No. 4. pp. 50-56. (In Russian)

[4] I.N. Yakovleva. How to calculate the discount rate and risk rate for a manufacturing enterprise, Spravochnikhe ekonomista. 2008. No. 9. pp. 24-33. (In Russian)

[5] Steinbach I., Staniaszek D. Discount rates in energy system analysis. Discussion Paper. Fraunhofer ISI, 2015. $18 \mathrm{p}$.

[6] Guidelines on the methods of the valuation of investment projects. Moscow: Ekonomika, 2000. 421 p. (In Russian)

[7] Yu.I. Zhdanov. The discount rate. The 10 modern methods of its calculation. Available at: http://www/ finrr.ru/stavka-diskontirovaniya.html

[8] P.L. Vilensky, V.N. Livshits, S.A. Smolyak. Valuation of investment projects. Principles and practices. Moscow: Delo, 2001. 832 p. (In Russian) 
[9] Yu.D. Kononov. Approaches to quantitative assessment of strategic threats to energy security, Energy Policy. 2014. No. 2. pp. 74-82.

[10]A.A.Makarov. Systems studies of the energy development: course of lectures. M.: Publishing House of MEI, $2015.280 \mathrm{p}$.

[11] A.A.Makarov and N.I.Voropai. Systems studies in the energy sector: methodology and results/ed. M. ERI $R A S, 2018.309$ p.

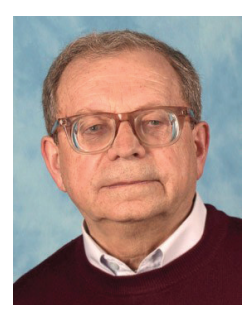

Yuri Kononov - Principal Researcher at the Melentiev Energy Systems Institute, SB RAS, Doctor of Economics, Professor, Meritorious Scientist of the Russian Federation.

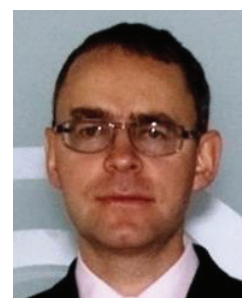

Dmitry Kononov - Ph. D., Senior researcher of Melentiev Energy Systems Institute of Siberian Branch of the Russian Academy of Sciences, Russia, Irkutsk. His research interests are consideration of the impact of the uncertainty factors on the methods for the evaluation of strategic threats to power industry development. 